\title{
Pertumbuhan Tanaman Lada (Pipper nigrum L.) Umur Satu Tahun pada Lahan Bekas Tambang dengan Penambahan Dosis Pupuk Hayati yang Berbeda
}

\author{
Growth of One Year Old Pepper (Pipper nigrum L.) in Post Tin Mining Land Using \\ Different Dosage Biofertilizer \\ Badriyah Badriyah ${ }^{1 *}$, Ismed Inonu ${ }^{1}$, Euis Asriani ${ }^{1}$ \\ ${ }^{1}$ Program Studi Agroteknologi, Fakultas Pertanian Perikanan dan Biologi, Universitas Bangka Belitung, \\ Bangka Belitung 33172 \\ ${ }^{*}$ Penulis untuk korespondensi: badriyahbafi@gmail.com
}

(diterima 12 Maret 2019, disetujui 25 April 2019)

Sitasi: Badriah B, Inonu I, Asriani E. 2019. Growth of one year old pepper (Pipper nigrum L.) in post tin mining land using different dosage biofertilizer. Jurnal Lahan Suboptimal: Journal of Suboptimal Lands. $8(2): 117-125$.

\begin{abstract}
The yield of pepper as important spice plant has been decreased due to the reduction of pepper planting area which are converted into tin mining area. One effort can be done is utilizing suboptimal lands that has low soil fertility. The aim of this research was to determine the effect of biofertilizer dosage on one year old pepper to growth in post tin mining land. This research had been conducted from February 2018 until June 2018 in post tin mining land owned by PT Timah at Dwi Makmur Village, Bangka. The research used expremental method with Completely Randomized Block Design (CRBD) with single factor. The factor was biofertilizer dosage: $(0,0 ; 0,5 ; 1,0 ; 5,0 ; 10,0 ;$ and $15,0 \mathrm{~g} / \mathrm{L} /$ plant $)$. The result showed enrichment biofertilizer significantly effect on chlorophyll content and number of branch, but not significantly on plants height, number of nodes, and leaf area. The treatment dosage $10 \mathrm{~g} / \mathrm{L} /$ plant $\left(1 \times 10^{8} \mathrm{cfu}\right)$ was the best inclined result growth of one year old pepper plant in post tin mining land.
\end{abstract}

Keywords: biofertilizer, dosage, growth, pepper, post tin mining

\begin{abstract}
ABSTRAK
Lada merupakan salah satu tanaman rempah yang produksinya terus menurun akibat penurunan luasan tanam menjadi area penambangan timah. Salah satu upaya yang bisa digunakan adalah dengan memanfaatkan lahan suboptimal yang memiliki tingkat kesuburan rendah. Tujuan dari penelitian ini adalah untuk mengetahui pengaruh dari pemberian pupuk hayati untuk pertumbuhan tanaman lada umur satu tahun dilahan beka tambangan timah. Penelitian ini dimulai dari bulan Febuari sampai bulan Juni 2018 di lahan pasca penambangan timah milik PT Timah di Desa Dwi Makmur, Bangka. Penelitian ini menggunakan Rancangan Acak kengkap (RAK) satu faktor. Faktor yang digunakan adalah pemberian dosis pupuk hayati $(0,0 ; 0,5 ; 1,0 ; 5,0 ; 10,0 ; 15,0 \mathrm{~g} / \mathrm{L} / \operatorname{tanaman})$. Hasil penelitian penambahan dosis pupuk hayati berpengaruh nyata terhadap kandungan klorofil dan pertambahan jumlah cabang, namun berpengaruh tidak nyata pada pertambahan tinggi tanaman, jumlah ruas, dan luas daun. Pemberaian dosis pupuk hayati $10 \mathrm{~g} / \mathrm{L} /$ tanaman
\end{abstract}


$\left(1 \times 10^{8} \mathrm{cfu}\right)$ memberikan pertumbuhan yang cenderung lebih baik pada tanaman lada umur satu tahun dilahan bekas tambang timah.

Kata kunci: dosis, lada, lahan bekas tambang timah, pertumbuhan, pupuk hayati

\section{PENDAHULUAN}

Lada (Pipper nigrum L.) merupakan tanaman perkebunan yang dimanfaatkan sebagai rempah dan menjadi tanaman perkebunan yang banyak dibudidayakan oleh masyarakat Bangka Belitung. Direktorat Jendral Perkebunan (2016), Provinsi Kepulauan Bangka Belitung merupakan daerah penghasil lada putih terbesar di Indonesia dengan luasan 45.382 ha pada tahun 2015. Luasan lahan tersebut jauh turun dari tahun 2004 yang mencapai 60.747 ha. Menurunnya luasan lahan tanaman lada dapat menyebabkan turunnya produksi lada.

Peningkatan produksi lada dapat diupayakan dengan menambah luas lahan budidaya melalui pemanfaatan lahan bekas tambang timah yang memiliki tailing berupa pasir. Yulita (2011) menyatakan bahwa penggunaan lahan untuk aktivitas penambangan mengalami peningkatan setiap tahunnya dengan laju rata-rata sekitar 1.315 ha/tahun. Lahan tersebut dapat dimanfaatkan sebagai lahan budidaya tanaman lada untuk meningkatkan produksi.

Lahan bekas tambang timah memiliki kondisi kritis dan belum termanfaatkan secara optimal yang didominasi oleh tailing. Tailing timah mengandung pasir dan kuarsa yang cukup tinggi dengan tingkat kesuburan yang sangat rendah. Menurut Subardja et al. (2012), mineral pasir tailing didominasi oleh kuarsa $>95 \%$ yang memiliki sedikit cadangan hara. Salah satu cara memperbaiki sifat tailing yaitu dengan melakukan pembenahan lahan. Menurut Ferry dan Towaha (2011), pembenahan lahan tailing sangat diperlukan karena lahan tersebut tidak akan mengalami perbaikan alami dalam jangka waktu yang singkat.

Proses pembenahan lahan dapat dilakukan dengan pemberian bahan pembenah tanah berupa amelioran dan bahan organik (Inonu et al., 2014). Pemberian bahan organik dapat ditunjang dengan pemberian pupuk hayati. Pupuk hayati dapat mengoptimalkan pertumbuhan dan produksi tanaman menjadi lebih baik melalui mekanismenya dengan cara mengkolonisasi rhizosper sehingga dapat menyediakan kebutuhan hara primer tanaman (Rahmawati 2005). Menurut Astari et al. (2014) pupuk hayati mengandung mikroba yang bermanfaat bagi tanaman. Adapun jenis mikroba yang terdapat pada pupuk hayati yang digunakan adalah Azotobacter sp., Bacillus sp., Azosperilium sp., Bhradyrhizobium sp., dan Methylobacterium sp. Pupuk hayati dapat meningkatkan pertumbuhan dan produksi tanaman.

Pemberian pupuk anorganik dengan dosis yang berbeda tanpa adanya penambahan pupuk hayati tidak berpengaruh terhadap pertumbuhan awal tanaman lada di lahan tailing berpasir (Andari, 2017). Penelitian dari Sumalia (2017) menunjukan pemberian pupuk hayati $2 \mathrm{~mL} / \mathrm{L}$ air berpengaruh terhadap parameter pertambahan jumlah daun, pertambahan diameter batang, dan kandungan klorofil total tanaman lada di media tailing pasir pasca penambangan timah. Pada tailing pasir lahan bekas tambang dengan penambahan pemberian bahan pembenah tanah berupa $60 \mathrm{~g}$ NPK, $20 \mathrm{~g}$ mikoriza, dan $2 \mathrm{cc} / \mathrm{L}$ pupuk hayati merupakan bahan pembenah terbaik untuk pertumbuhan awal lada (Rinaldi, 2017). Kartikawati et al. (2017) menyatakan bahwa aplikasi pupuk hayati $10 \mathrm{~g} / \mathrm{tanaman}$ menghasilkan pertumbuhan vegetatif tanaman lada yang lebih baik dibandingkan kontrol.

Penggunaan pupuk hayati dapat meningkatkan pertumbuhan tanaman lada, namun belum diketahui dosis yang optimum untuk pertumbuhan tanaman lada 
pada umur satu tahun. Oleh karena itu, perlu dilakukan penelitian mengenai pertumbuhan tanaman lada (Piper ningrum L.) umur satu tahun pada lahan bekas tambang timah dengan penambahan dosis pupuk hayati yang berbeda. Hasil penelitian diharapkan dapat memberikan informasi pertumbuhan lada dilahan bekas tambang timah umur satu tahun dengan penambahan pupuk hayati. Tujuan penelitian ini adalah untuk mengetahui pengaruh dari pemberian pupuk hayati untuk pertumbuhan tanaman lada umur satu tahun di lahan bekas tambangan timah.

\section{BAHAN DAN METODE}

Penelitian dilaksanakan di lahan bekas tambang timah milik PT Timah di Desa Dwi Makmur, Kecamatan Merawang Kabupaten Bangka. Penelitian ini dilaksanakan dari bulan Februari 2018 sampai Juni 2018. Penelitian ini menggunakan metode eksperimen. Rancangan yang digunakan adalah Rancangan Acak Kelompok (RAK). Setiap perlaakuan diulang tiga kali dan setiap unit pecobaan terdiri dari dua sampel tanaman. Faktor yang diteliti adalah dosis pupuk hayati $(0 ; 0,5 ; 1,0 ; 5,0 ; 10,0 ; 15,0$ $\mathrm{g} / \mathrm{L} / \mathrm{tanaman})$.

Lahan penelitian merupakan lahan bekas tambang timah yang sudah ditanami tanaman lada. Sebelum aplikasi pupuk hayati, tanaman lada dilakukan pemupukan anorganik dengan dosis anjuran yaitu sebanyak $71 \mathrm{~g}$ urea, $44 \mathrm{~g}$ SP-36 dan $53 \mathrm{~g}$ $\mathrm{KCl}$ per tanaman/tahun serta ditambahkan kompos sebanyak $5 \mathrm{~kg}$ ke masing-masing lubang tanam. Pemeliharaan tanaman meliputi pemangkasan, penyiangan gulma, pengendalian hama dan penyakit, serta penyiraman. Pengenceran pupuk hayati dibiarkan selama 2 x 24 jam sebelum pengaplikasian ke media, kemudian diaplikasikan pada tanaman lada.

Peubah pertumbuhan tanaman lada diantaranya jumlah ruas, jumlah cabang, dan tinggi tanaman diamati pada minggu ke 0 , 4, 8, dan 12 setelah aplikasi pupuk hayati, peubah kandungan klorofil diamati pada minggu ke 12 setelah aplikasi pupuk hayati, dan peubah luas daun diamati pada minggu ke 0 dan ke 12 setelah aplikasi pupuk hayati. Data hasil penelitian dianalisis statistika dengan Analysis of variance (ANOVA) dan uji Duncan's Multiple Range Test (DMRT).

\section{HASIL}

Hasil analisis awal kandungan kimia lahan bekas tambang memiliki tingkat kesuburan tanah yang rendah. Tabel 1 menunjukkan bahwa kandungan C-Organik $(0,39 \%), \mathrm{N}-$ Total $(0,01 \%)$, serta P2O5 potensial $(1,12 \mathrm{mg} / 100 \mathrm{~g})$ tergolong sangat rendah, kandungan kimia $\mathrm{K} 2 \mathrm{O} \quad(0,24$ $\mathrm{mg} / 100 \mathrm{~g}$ ) tergolong rendah, dan $\mathrm{pH} \mathrm{H} 2 \mathrm{O}$ $(5,05)$ dan $\mathrm{KCl}(4,36)$ tergolong masam.

Analisis ragam menunjukkan bahwa pemberian dosis pupuk hayati yang berbeda pada tanaman lada umur satu tahun berpengaruh nyata pada peubah jumlah cabang dan kandungan klorofil, dan berpengaruh tidak nyata pada peubah pertambahan tinggi tanaman, pertambahan jumlah ruas, dan pertambahan luas daun. Hasil analisis ragam pertumbuhan tanaman lada umur satu tahun pada lahan bekas tambang timah dengan penambahan pupuk hayati (Tabel 2).

Perbedaan rerata kandungan klorofil berdasarkan Duncan's Multiple Range Test (DMRT) (Tabel 3). Penambahan dosis pupuk hayati perlakuan B4 (10 g/L/tanaman) memberikan pengaruh yang lebih baik pada peubah kandungan klorofil, berbeda nyata dengan perlakuan B5 (15 $\mathrm{g} / \mathrm{L} /$ tanaman) dan B1 (0,5 g/L/tanaman). Perbedaan rerata Hasil dari pertambahan jumlah cabang berdasarkan Duncan's Multiple Range Test (DMRT) (Tabel 4).

Hasil pengamatan pertambahan jumlah cabang dilakukan selama 12 minggu setelah aplikasi (Gambar 1). Pola pertambahan jumlah cabang hampir sama dengan pola pertambahan jumlah ruas (Gambar 2). Hal ini disebabkan karena pada setiap cabang memiliki ruas sehingga pola pertambahan 
ruas mengikuti pola pertambahan cabang pada setiap perlakuan. Hasil pertambahan

kemiripan

hasil pertambahan tinggi

luas daun (Gambar 4) menunjukan perlakuan.

(Gambar 3) berdasarkan

Tabel 1. Hasil analisis ragam tanaman lada pada minggu ke-12 setelah aplikasi penambahan dosis pupuk hayati yang berbeda

\begin{tabular}{llc}
\hline Peubah & Pr>F & KK (\%) \\
\hline Kandungan Klorofil & $0,02^{*}$ & 23,64 \\
Jumah Cabang & $0,02^{*}$ & 30,73 \\
Jumlah Ruas & $0,35^{\text {tn }}$ & 41,29 \\
Tinggi Tanaman & $0,93^{\text {tn }}$ & 26,30 \\
Luas Daun & $0,70^{\text {th }}$ & 25,96
\end{tabular}

Keterangan: KK $=$ Koefisien Keragaman, $\mathrm{Pr}>\mathrm{F}=$ Nilai Probability, $*$ = Berpengaruh nyata pada uji $\mathrm{F}$ taraf kepercayaan $95 \%$, tn = Berpengaruh tidak nyata pada uji $\mathrm{F}$ taraf kepercayaan $95 \%$

Tabel 2. Kandungan klorofil tanaman lada pada minggu ke-12 setelah aplikasi penambahan dosis pupuk hayati yang berbeda

\begin{tabular}{lc}
\hline Dosis pupuk (g/L/tanaman) & Kandungan Klorofil (CCI) \\
\hline B0 $=0$ & $9,76^{\text {abc }}$ \\
B1 $=0,5$ & $5,58^{\mathrm{c}}$ \\
B2 $=1$ & $9,24^{\text {bc }}$ \\
B3 $=5$ & $11,096^{\text {ab }}$ \\
B4 10 & $12,96^{\mathrm{a}}$ \\
B5 $=15$ & $7,76 b^{c}$ \\
\hline
\end{tabular}

Keterangan: Angka-angka yang diikuti oleh huruf yang sama pada kolom yang sama berarti berbeda tidak nyata pada uji DMRT $\alpha=0,05$

Tabel 3. Rerata pertambahan jumlah cabang tanaman lada umur satu tahun pada lahan bekas tambang timah dengan penambahan dosis pupuk hayati yang berbeda

\begin{tabular}{lc}
\hline Dosis (g/L/tanaman) & Pertambahan Jumlah Cabang \\
\hline B0 $=0$ & $8,17^{\mathrm{b}}$ \\
B1 $=0,5$ & $8,83^{\mathrm{b}}$ \\
B2 $=1$ & $7,33^{\mathrm{b}}$ \\
B3 $=5$ & $6,33^{\mathrm{b}}$ \\
B4 $=10$ & $14,83^{\mathrm{a}}$ \\
B5 $=15$ & $14,83^{\mathrm{a}}$ \\
\hline
\end{tabular}

Keterangan: Angka-angka yang diikuti oleh huruf yang sama pada kolom yang sama berarti berbeda tidak nyata pada uji DMRT $\alpha=0,05$

Tabel 4. Rerata pertambahan jumlah cabang tanaman lada pada minggu ke-12 setelah aplikasi penambahan dosis pupuk hayati yang berbeda

\begin{tabular}{lc}
\hline Dosis (g/L/tanaman) & Pertambahan Jumlah Cabang \\
\hline B0 $=0$ & $8,17^{\mathrm{b}}$ \\
B1 $=0,5$ & $8,83^{\mathrm{b}}$ \\
B2=1 & $7,33^{\mathrm{b}}$ \\
B3 $=5$ & $6,33^{\mathrm{b}}$ \\
B4=10 & $14,83^{\mathrm{a}}$ \\
B5 $=15$ & $14,83^{\mathrm{a}}$ \\
\hline
\end{tabular}

Keterangan: Angka-angka yang diikuti oleh huruf yang sama pada kolom yang sama berarti berbeda tidak nyata pada uji DMRT $\alpha=0,05$ 


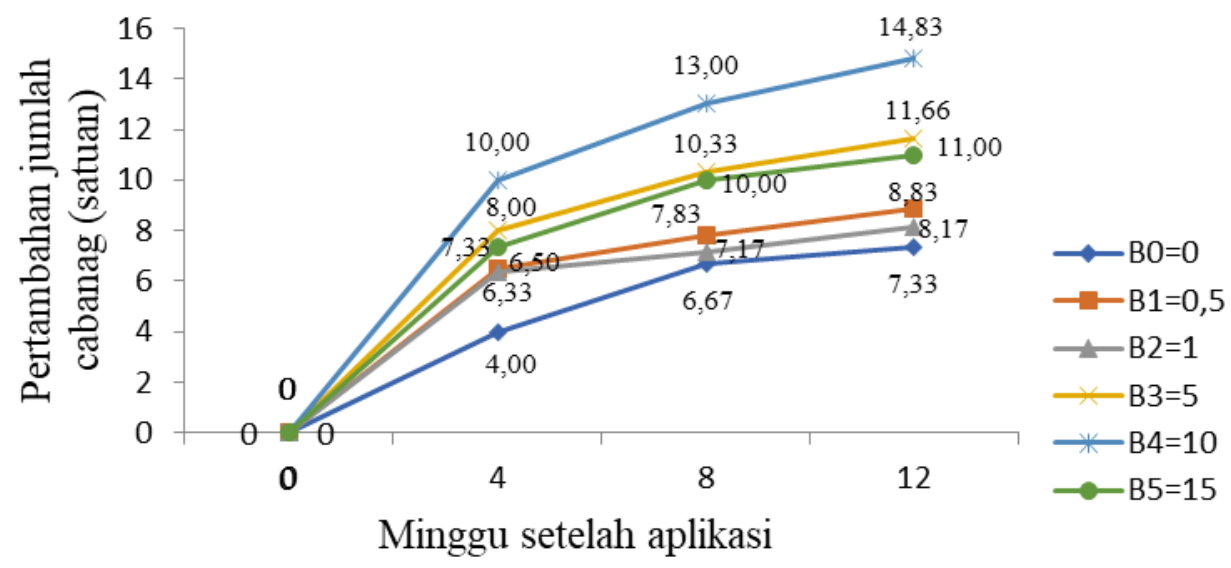

Gambar 1. Pertambahan jumlah cabang tanaman lada selama 12 minggu setelah aplikasi pada lahan bekas tambang timah dengan penambahan dosis pupuk hayati yang berbeda

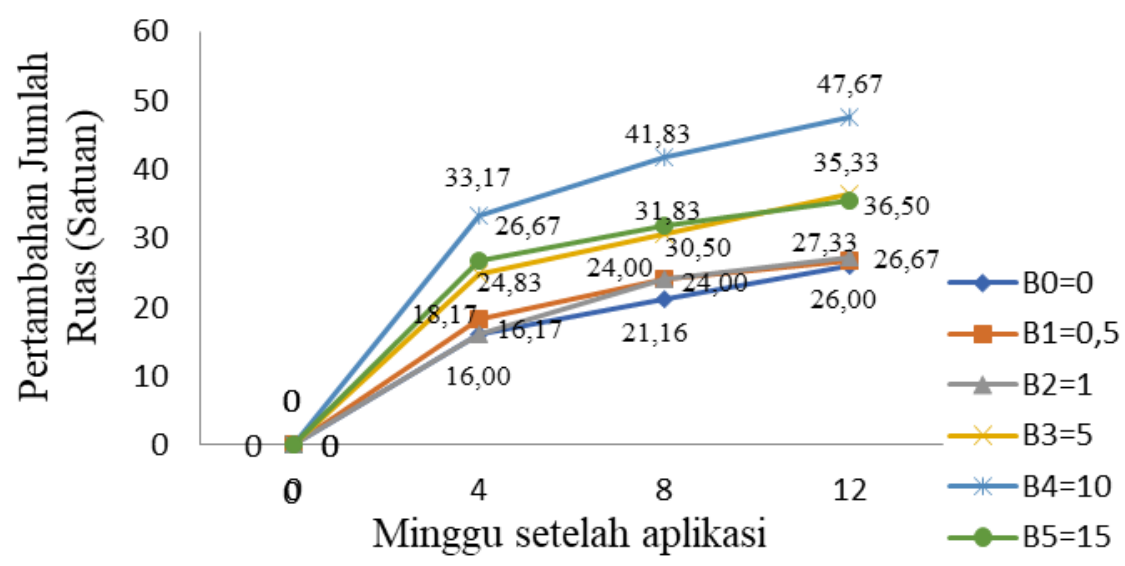

Gambar 2. Pertambahan jumlah ruas tanaman lada selama 12 minggu setelah aplikasi pada lahan bekas tambang timah dengan penambaha.n dosis pupuk hayati yang berbeda

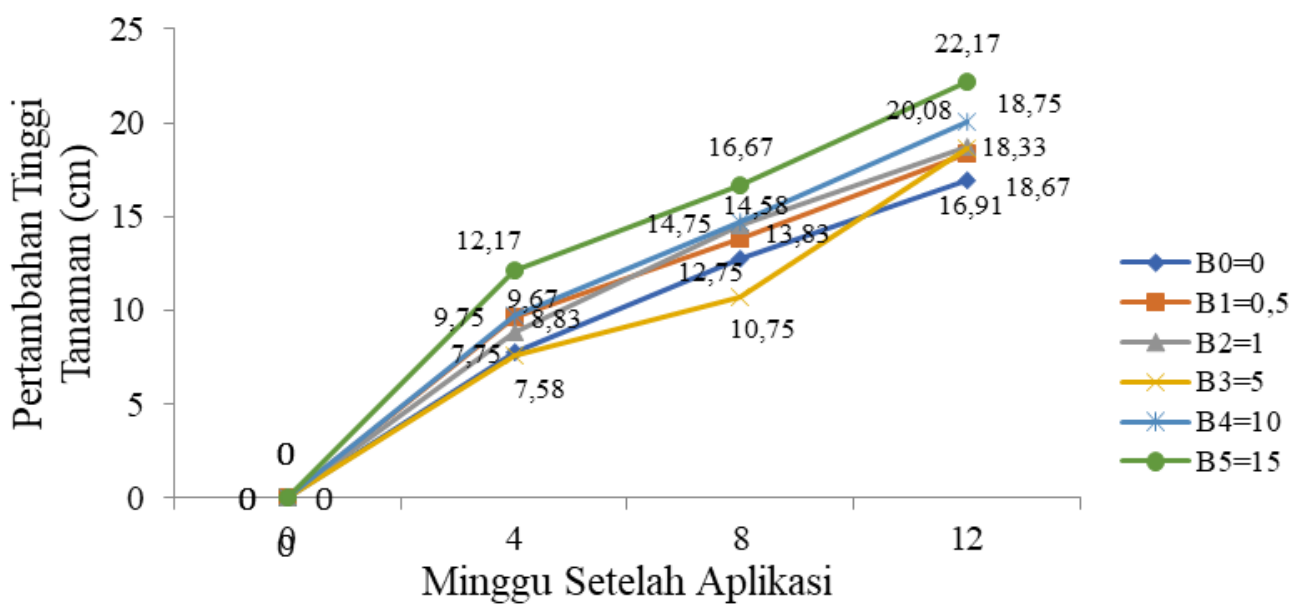

Gambar 3. Pertambahan tinggi tanaman lada selama 12 minggu setelah aplikasi pada lahan bekas tambang timah dengan penambahan dosis pupuk hayati yang berbeda 


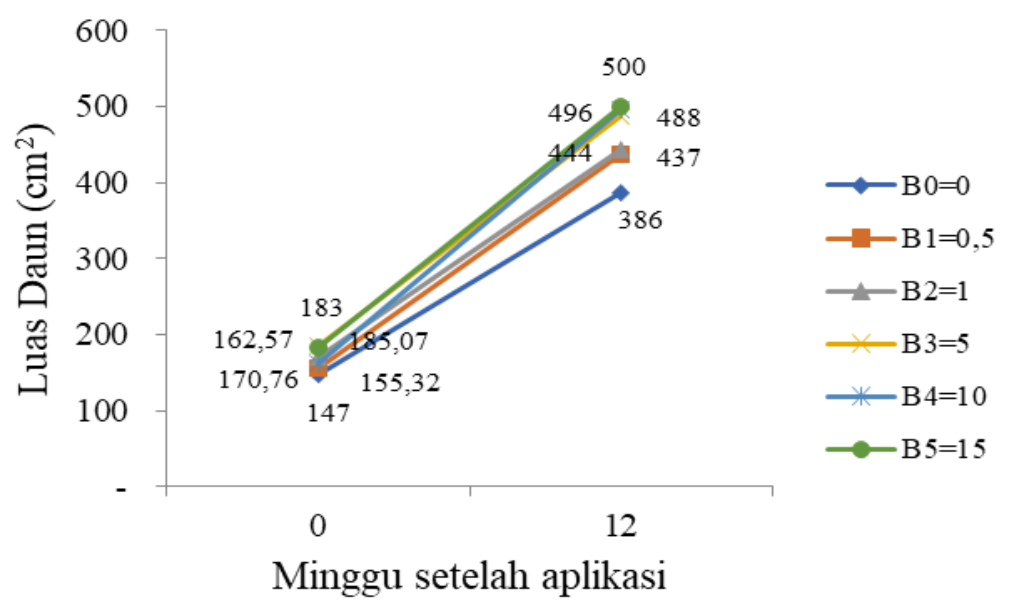

Gambar 4. Luas daun tanaman lada selama 12 minggu setelah aplikasi pada lahan bekas tambang timah dengan penambahan dosis pupuk hayati yang berbeda

\section{PEMBAHASAN}

Hasil analisis awal kandungan kimia lahan bekas tambang memiliki tingkat kesuburan tanah yang rendah. Tabel 1 menunjukkan bahwa kandungan C-Organik $(0,39 \%), \mathrm{N}$ - Total $(0,01 \%)$, serta P2O5 potensial $(1,12 \mathrm{mg} / 100 \mathrm{~g})$ tergolong sangat rendah, kandungan kimia $\mathrm{K} 2 \mathrm{O} \quad(0,24$ $\mathrm{mg} / 100 \mathrm{~g}$ ) tergolong rendah, dan $\mathrm{pH} \mathrm{H} 2 \mathrm{O}$ $(5,05)$ dan $\mathrm{KCl} \quad(4,36)$ tergolong masam.Menurut Dhalimi dan Syakir (2008) setiap $\mathrm{kg}$ lada membutuhkan unsur-unsur dari dalam tanah sebanyak $32 \mathrm{~g} \mathrm{~N}, 5 \mathrm{~g}$ P2O5, 28 g K2. Djaenudin et al. (2011) menambahkan bahwa berdasarkan kriteria kesesuaian untuk tanaman lada $\mathrm{pH}$ 4,0-5,0 dan C-Organik sebesar 0,39 tergolong kelas yang sesuai. Sitorus et al. (2008) melaporkan bahwa unsur hara makro pada lahan bekas tambang sangat rendah $\mathrm{N}$ 0,02\%, P 15 ppm, dan K 46 ppm. Menurut Ferry dan Towaha (2011) pada lahan bekas tambang nitrogen dan kalium mudah tercuci karena lahan bekas tambang mempunyai kadar pasir tinggi (tailing). Sesuai dengan pendapat Nurtjahya et al. (2008) tanah bekas tambang timah (tailing timah) berbeda dengan tanah asli, tailing timah mengandung fraksi pasir lebih dari 94\%, fraksi liat kurang dari 3\%, dan kandungan bahan organik C-organik kurang dari $2 \%$.

Analisis ragam menunjukkan bahwa pemberian dosis pupuk hayati pada tanaman lada umur satu tahun berpengaruh nyata pada peubah jumlah cabang dan kandungan klorofil, dan berpengaruh tidak nyata pada peubah pertambahan tinggi tanaman, pertambahan jumlah ruas, dan pertambahan luas daun.

Kandungan klorofil merupakan indikator respon fisiologis tanaman terhadap pasokan hara, kondisi lingkungan dan faktor lainya. Hendriyani dan Setiari (2009) menegaskan bahwa pembentukan klorofil dipengaruhi oleh beberapa faktor yaitu gen, cahaya, dan unsur $\mathrm{N}, \mathrm{Mg}$, Fe sebagai pembentuk katalis dalam sintesis klorofil.Pembentukan klorofil yang meningkat diduga karena pupuk hayati yang digunakan mengandung mikroorganisme penambat $\mathrm{N}$, pelarut $\mathrm{P}$ dan penghasil fitohormon. Menurut Syarifudin (2002) mikroorganisme yang umum digunakan sebagai bahan aktif pupuk hayati ialah mikroorganisme penambat $\mathrm{N}$, pelarut $\mathrm{P}$ dan mikroorganisme penghasil zat pengatur tumbuh (ZPT). Mikroba-mikroba yang memiliki kemampuan untuk menambat $\mathrm{N}$ bebas, dapat melakukan fiksasi nitrogen dan men dekomposisi nitrogen menjadi ion-ion nitrat dan amonium yang dapat diserap tanaman. ZPT yang dihasilkan oleh mikroorganisme yang terdapat pada pupuk hayati berupa fitohormon jenis IAA, $\mathrm{GA}_{3}$ dan Sitokinin. Widawati et al. (2010) menyatakan kandungan klorofil pada tanaman yang diberi penambahan bakteri penambat $\mathrm{N}$ 
memberikan jumlah kandungan klorofil yang terbaik. Bachtiar et al. (2016) menambahkan bahwa pupuk hayati yang mengandung bakteri penambat $\mathrm{N}$ memberikan pengaruh terbaik terhadap kandungan klorofil yang digunakan sebagai parameter pertumbuhan tanaman. Menurut Suharja dan Sutarno (2009) jumlah kandungan nitrogen tanaman dapat berpengaruh terhadap hasil fotosintesis melalui enzim fotosintetik maupun kandungan klorofil yang terbentuk. RongHua et al. (2006) menyatakan bahwa tinggi rendahnya kandungan klorofil mempengaruhi laju fotosintesis dan fotosintat yang dihasilkan.

Fotosintat yang dihasilkan digunakan untuk pembentukan struktur tanaman, seperti daun, batang, cabang dan akar. Hasil analisis ragam menunjukkan pemberian dosis pupuk hayati memberikan pegaruh nyata terhada pertambahan jumlah cabang. Pertambahan jumlah cabang disebabkan oleh adanya pemangkasan terhadap tanaman lada pada awal penelitian, sehingga dari bekas pemangkasan tumbuh cabang baru. Cabang baru ini merupakan organ muda yang membutuhkan hasil fotosintat lebih banyak sehingga fotosintat lebih banyak didistribusikan kebagian cabang. Harmer (2000) mengungkapkan bahwa dengan adanya tunas baru (bakal cabang) yang tumbuh maka penyaluran fotosintat lebih banyak didistribusikan ke tunas baru yang tumbuh. Sarawa et al. (2014) menyebutkan bahwa presentase distribusi fotosintat lebih banyak dialirkan pada organ yang masih muda atau masih aktif dalam pertumbuhanya. Dhalimi dan Syakir (2008) menyatakan bahwa pemberian pupuk NPKMg dengan penambah ZPT pada tanaman lada umur 11 bulan setelah tanam hanya berpengaruh nyata terhadap peubah jumlah cabang. Penelitian Gunadi et al. (2011) tanaman yang memiliki dua cabang memberikan tinggi tanaman yang lebih tinggi di bandingkan tanaman yang memiliki tiga cabang. Hal ini dikarenakan adanya persaingan atau kompetisi dalam penggunaan hasil fotosintesis dan menyebabkan kurangnya distribusi fotosintat pada peubah lainya, seperti pertambahan tinggi tanaman, pertambahan luas daun dan pertambahan jumlah ruas.

Berdasarkan deskripsi pola pertumbuhan tanaman, saat tanaman memasuki fase generatif distribusi fotosintat akan lebih di utamakan pada organ generatif seperti bunga, buah dan biji. Pada tanaman lada umur satu tahun tanaman sudah mulai memasuki fase generatif. Hal ini di buktikan dengan beberapa tanaman lada yang sudah memiliki cabang buah.

Uji lanjut Duncan's Multiple Range Test (DMRT) menunjukan bahwa perlakuan 10 g/L/tanaman menjadi perlakuan terbaik dibandingkan dengan perlakuan lainya. Hal ini disebabkan perlakuan $10 \mathrm{~g} / \mathrm{L} / \mathrm{tanaman}$ dengan kepadatan mikroba $1 \times 10^{8} \mathrm{cfu}$ memiliki kepadatan mikroba yang tepat untuk diaplikasikan dan memungkinkan mikroba dapat beraktivitas. Kepadatan mikroba standar khusus pada pupuk hayati sesuai peraturan pemerintah no 70 tahun 2011 adalah $10^{7}$ cfu dengan memfasilitasi ketersediaan nutrisi bagi mikroba. Setiawan et al. (2016) menyebutkan bahwa kepadatan mikroba $10^{7}$ cfu yang diberikan di lahan sawah dan ditambah dengan kompos keong hanya mampu tumbuh dan berkembang hingga 56 hari setelah aplikasi. Sehingga perlakuan $10 \mathrm{~g} / \mathrm{L} / \operatorname{tanaman}$ menjadi pilihan dosis yang optimum dibandingkan dengan perlakuan $15 \mathrm{~g} / \mathrm{L} / \mathrm{tanaman}$. Putri et al. (2010) menyatakan bahwa pada media dengan kandungan bahan organik sedikit jumlah kepadatan mikroba mengalami penurunan akibat adanya persaingan dalam penyerapan bahan organik untuk mempertahankan viabilitas.

Perlakuan 5 g/L/tanaman dan 1 g/L/tanaman dengan kepadatan mikroba sebesar $10^{7}$ cfu belum efektif digunakan di lahan kritis seperti lahan bekas tambang, $0,5 \mathrm{~g} / \mathrm{L} / \mathrm{tanaman}$ dengan kepadatan mikroba $10^{6} \mathrm{cfu}$ menujunkkan hasil perlakuan yang belum optimum hal ini disebabkan penggunaan dosis masih rendah. Sinulingga et al. (2015) menyatakan penggunaan dosis 
dengan jumlah kepadatan mikroorganisme yang rendah belum cukup untuk meningkatkan produktivitas tanaman yang berdampak pada pertumbuhan tanaman.

Berdasarkan Gambar 1, 2, dan 3 pertumbuhan tanaman lada pada minggu ke-4 setelah aplikasi mengalami peningkatan yang lebih tinggi dibandingkan pada minggu ke-8 dan minggu ke-12 setelah aplikasi. Aktivitas dan viabilitas mikroba pada minggu ke- 4 mikroba masih bertahan dan melakukan aktivitas karena adanya nutrisi dari kompos yang diberikan sebelum aplikasi, sedangkan pada minggu ke-8 dan minggu ke-12 jumlah mikroba mulai menurun.

Penurunan mikroba ini karena nutrisi dari kompos sudah mulai habis dan juga karena pencucian baik karena penyiraman ataupun hujan. Widawati et al. (2006) mengungkapkan pada lahan yang miskin unsur hara jumlah kepadatan mikroba yang tepat dapat memaksimalkan aktivitas mikroba dalam menyediakan usur hara bagi tanaman. Salah satu faktor yang mempengaruhi aktivitas kerja mikroba adalah lingkungan, jumlah mikroba yang banyak tetapi tidak didukung oleh kondisi lingkungan yang baik dapat menyebabkan persaingan antara mikroba dan tanaman untuk mendapatkan kebutuhanya.

Urutan hasil pengamatan peubah pertambahan jumlah cabang dari jumlah yang terbanyak hingga terendah yaitu pada perlakuan $10 \mathrm{~g} / \mathrm{L} / \mathrm{tanaman}, 15 \mathrm{~g} / \mathrm{L} / \mathrm{tanaman}$, $5 \mathrm{~g} / \mathrm{L} / \tan a m a n, \quad 1 \mathrm{~g} / \mathrm{L} / \tan a m a n, \quad 0,5$ $\mathrm{g} / \mathrm{L} / \tan a m a n$, dan $0 \mathrm{~g} / \mathrm{L} / \mathrm{tanaman}$, dan pola pertambahan jumlah cabang ini mirip dengan urutan hasil pengamatan peubah pertambahan jumlah ruas. Hal ini disebabkan karena pada setiap cabang memiliki ruas sehingga pola pertambahan ruas mengikuti pola pertambahan cabang pada setiap perlakuan. Hasil pertambahan luas daun menunjukan kemiripan hasil pertambahan tinggi tanaman berdasarkan perlakuan. Sesuai dengan pernyataan faktor yang mempengaruhi luas daun adalah tinggi tanaman dan banyaknya sinar matahari yang terserap oleh tanaman.

\section{KESIMPULAN}

Pemberian dosis pupuk hayati sebanyak $10 \mathrm{~g} / \mathrm{L} / \tan a m a n\left(1 \times 10^{8} \mathrm{cfu}\right)$ memberikan pertumbuhan yang cenderung lebih baik pada tanaman lada umur satu tahun di lahan bekas tambang timah.

\section{DAFTAR PUSTAKA}

Andari GD. 2017. Pengaruh dosis pupuk anorganik terhadap pertumbuhan awal lada di lahan tailing berpasir. [Skripsi]. Balunijuk: Universitas Bangka Belitung.

Astari W, Purwani KI, Anugerahani. 2014. Pengaruh aplikasi pupuk hayati terhadap pertumbuhan dan produktivitas taman tomat (Solanum lycopersicum L). Var. Tombatu di PT Petrokimia Gresik. Jurnal Sains dan Seni Pomits. 2:(1):1-4.

Dhalimi A, Syakir M. 2008. Pertumbuhan dan produksi lada perdu yang dipupuk Npk mg dan diaplikasikan zat pengatur tumbuh Triakontanol. Buletin Balitri. 19 (1): 47-56.

Direktorat Jendral Perkebunan. 2016. Statistik Perkebunan Indonesia. Jakarta: Sekretariat Direktorat Jendral Perkebunan.

Djaenudin D, Marwan H, Subagjo H, Hidayat A. 2011. Petunjuk Teknis Evaluasi Lahan untuk Komoditas Pertanian. Bogor: Balai Besar Litbang Sumberdaya Lahan Pertanian, Badan Litbang Pertanian.

Ferry Y, Towaha J. 2011. Pengaruh komposisi pupuk N, P, dan $\mathrm{K}$, terhadap pertumbuhan dan produksi lada pada tanah bekas tambang timah di Bangka. Buletin Ristri 2 (3): 305-310.

Gunadi NR, Maaswinkel TK, Moekasan, Prabaningrum L, Subhan, Adiyoga W. 2011. Pengaruh jumlah cabang per tanaman terhadap pertumbuhan dan hasil tiga varietas paprika. Jurnal Hortikultura. 21(2): 124-134

Harmer R. 2000. Differences in growth and branch production by young plants of two provenances of quercus robur L. Forestry. 73(3): 271- 281. 
Hendriyani IS, Setiari N. 2009. Kandungan klorofil dan pertumbuhan kacang panjang (Vigna sinensis) pada tingkat pemberian air yang berbeda. Jurnal Sains \& Matematika. 17(3):145-150.

Inonu I, Khodijah NS, Supriadi A. 2014. Budidaya pakchoy (Brasssica rapa L.) di lahan tailing pasir bekas penambangan timah dengan amelioran pupuk 39 organik dan pupuk NPK. Palembang. Jurnal Nasional Lahan Suboptimal. 3(1):76-82.

Kartikawati A, Trislawati, Darwati I. 2017. Pemanfaatan pupuk hayati (biofertilizer) pada tanaman rempah dan obat. Prospektif. 16(1): 33-43.

Putri MS, Anas I, Hazra F, Citraresmini A. 2010. viabilitas inokulan dalam bahan pembawa gambut, kompos, aran batok dan zeolit yang disetril denga iridiasi sinar gamma $\mathrm{C} 0-60$ dan mesin berkas elektron. Jurnal Tanah dan Lingkungan. 12(1): 23-30.

Rahmawati N. 2005. Pemanfaatan Biofertilizer pada Pertanian Organik. Medan: USU Repository.

Rinaldi R. 2017. Pemberian bahan pembenah tanah pada lahan tailing pasir pasca penambangan timah untuk pertumbuhan awal tanaman lada (Piper nigrum L). [Skripsi]. Balunijuk: Universitas Bangka Belitung.

Rong-Hua L, Pei-guo G, Baum M, Grando S, Ceccareli S. 2006. Evaluation of chlorophyl contet and flourescence parameters as indicator of drought tolerane in barley. Agricultural Science China. 5(1): 751-757.

Sarawa, Anas AA, Asrida. 2014. Pola distribusi fotosintat pada fase vegetetatif beberapa varietas kedelai pada tanah masam di Sulawesi tenggara. Jurnal Agroteknologi. 4(1): 26-31.

Setiawan A, Bintang M, Falah S. 2016. Aplikasi pupuk organik (bio-fertilier) diperkaya konsorsum bakteri dan keong mas (Pamoacea canliculata) pada pembungaan padi ciherang. Current Biochemistry. 3(2): 91-101.

Sinulingga ESR, Ginting J, Sabrina T. 2015. Pengaruh pemberia pupuk hayati cair dan pupuk NPK terhadap pertumbuhan bibit kelapa sawait pre nurseri. Jurnal online Agroekoteknoogi. 3(3): 1219-1225.

Sitorus SRP, Kusumastuti E, Badri NL. 2008. karakteristik dan teknik rehabilitasi lahan pasca penambangan timah di Pulau Bangka dan Singkep. Jurnal Tanah dan Iklim. (27): 57-73

Subardja D, Antonius K, Erna S. 2012. Teknologi Pemulihan Lahan Bekas Tambang Timah untuk Pertanian di Bangka Belitung. Bogor: Balai tanah.

Sumalia. 2017. pengaruh dosis mikoriza dan pupuk hayati terhadap pertumbuhan tanaman lada di Media Tailing Pasir. [Skripsi]. Balunijuk: Universitas Bangka Belitung.

Syarifudin A. 2002. Teknik identifikasi mikroorganisme penyedia unsur hara tanaman pada ultisol pulau buru. Buletin Teknik Pertanian. 1(7): 21-24.

Widawati S, Suliasih. 2006. Augmentasi bakteri pelarut fosfat (BPF) potensial sebagai Pemacu pertumbuhan caysin (Brasica caventis Oed.) di tanah marginal. Biodiversitas. 7(1): 10-14.

Widawati S, Suliasih, Muharam A. 2010. Pengaruh kompos yang diperkaya bakteri penambat Nitrogen dan pelarut posfat terhadap pertumbuhan tanaman kapri dan aktivitas enzim fosfatase dalam tanah. Jurnal Hortikultura. 20(3): 207-215.

Yulita. 2011. Perubahan penggunaan lahan dalam hubunganya dengan aktivitas pertambangan di kabupaten Bangka Tengah [Tesis]. Bogor: Institut Pertanian Bogor. 